\title{
Platelet augmentation activity of andrographis paniculata extract and andrographolide against cyclophosphamide induced thrombocytopenia in
}

\section{rats}

\begin{abstract}
Objective: Platelet augmentation activity Andrographis paniculata extract (APE) and its active constituent Andrographolide was evaluated in male Sprague-Dawley rats by inducing thrombocytopenia with Cyclophosphamide. Andrographis paniculata is a king of biter plants belongs to the family Acanthaceae. It is traditionally used to cure most of the ailments, especially in India subcontinent for the treatment of dengue fever where the platelet count is less
\end{abstract}

Methods: The study was performed initially with APE and later with Andrographolide in two different time periods. Thrombocytopenia was induced by subcutaneous injection of Cyclophosphamide at $25 \mathrm{mg} / \mathrm{kg}$ for 3 days. After 7 days, the test groups were treated with APE at a dose of $200 \mathrm{mg} / \mathrm{kg}$ and $400 \mathrm{mg} / \mathrm{kg}$ and Andrographolide at $3 \mathrm{mg} / \mathrm{kg}$ and $6 \mathrm{mg} / \mathrm{kg}$ respectively until 21 days

Results: The results indicated that after treatment with APE significant increase $(\mathrm{p} \leq 0.05)$ in the platelet number $(5.73 \pm 0.20$ to $7.59 \pm 0.28 ; 6.02 \pm 0.27$ to $8.50 \pm 0.18$ ) in a dose dependant manner. Similarly treatment with Andrographolide a significant $(\mathrm{P}<0.05)$ increase in the platelet count $(4.97 \pm 0.27$ to $7.24 \pm 0.34 ; 5.03 \pm 0.12$ to $7.58 \pm 0.45)$ was found. Correspondingly a significant decrease in $(\mathrm{p} \leq 0.05)$ bleeding time and clotting time $(\mathrm{p} \leq 0.05)$ was observed with APE and Andrographolide.

Conclusion: The current study supports platelet augmentation activity of $A$. paniculata and its active constituent Andrographolide which may have beneficial effect in dengue hemorrhagic fever.

Keywords: andrographis paniculata, andrographolide, thrombocytopenia, platelet augmentation, cyclophosphamide, dengue fever
Volume 2 Issue 4 - 2015

Nagarajan Venkataraman,' Suman

Pamukuntla, ${ }^{2}$ Jithender Banoth, ${ }^{2}$ Pandu

Boini, ${ }^{2}$ Sunitha Sampathi, ${ }^{3}$ Veerabhadra

Swami, ${ }^{2}$ Venu Talla ${ }^{2}$

'Dr. MGR Medical University, India

${ }^{2}$ Department of Pharmacology and Toxicology, National Institute of Pharmaceutical Education and Research (NIPER), India ${ }^{3}$ Department of Pharmaceutics, National Institute of

Pharmaceutical Education and Research (NIPER), India

Correspondence: Talla Venu, National Institute of Pharmaceutical Education and Research (NIPER) Hyderabad Address: IDPL R\&D Center, Balanagar, Hyderabad, Telangana-500037, India, Tel +9l-9885421762, Fax +9I-0402307375।,Email tallavenu@gmail.com

Received: June 23, 2015 | Published: July 10, 2015
Abbreviations: APE, andrographis paniculata extract; ANDLE, andrographolide; TCP, thrombocytopenia; RBC, red blood cell; Cpx, cyclophosphamide; CSF, colony stimulating factor

\section{Introduction}

Andrographis paniculata (neelavemu, neelavembu, kalmegh) is also known as king of bitter plants belongs to the family Acanthaceae and is traditionally used in the treatment of multiple ailments. ${ }^{1}$ It contains various chemical constituents like lactones, diterpenoids, diterpene glycosides, flavanoids, among which andrographolide, neo Andrographolide, Isoandrographolide, 14-deoxy-11, 12-dideandrgrapholide, are major components and xanthones likedihydroxy-dimethoxy xanthone, trimethoxy-1-hydroxy xanthine are minor components. A. paniculata has multiple pharmacological actions like-anti-inflammatory, anti-diabetic, anti-ulcer, anti-cancer, anti-angiogenic, anti-viral, hepatoprotective, and immunomodulatory, anti-microbial, anti-parasitic, anti-malarial and anti-oxidant activities..$^{2-4}$ It also has cardiovascular activities like anti-hypertensive, anti-platelet, cardio protective activities. A. paniculata is also used in the treatment of common cold, bronchitis etc. ${ }^{5}$

Platelets are type of blood cells produced from megakaryocytes by the action of a major hormone thrombopoietin. ${ }^{6}$ Colony stimulating factor (CSF) and cytokine like IL-3, Il-6, and IL-11 also play role in the thrombopoiesis. ${ }^{7}$ Platelets are mainly involved in the blood clotting mechanism to control the blood loss during injury along with other blood coagulation factors. Thrombocytopenia (Low platelet count) is a serious life threatening condition and is either due to decreased production of platelets from bone marrow or increased destruction of platelets due to immune reaction. ${ }^{8}$ Thrombocytopenia is mainly linked to the prolonged bleeding and clotting time due to insufficient number of platelets in blood. ${ }^{9}$ The decrease in normal platelet count is mainly caused by genetic disorders or infections like dengue hemorrhagic fever, chicken pox, parvovirus, rubella, and several bacterial infections like tuberculosis..$^{10}$ Most of the chemotherapeutic agents can cause thrombocytopenia as an adverse effect during the period of treatment. Based on this effect, cyclophospamide (CPx) was used to induce thrombocytopenia in experimental animals for the evaluation of platelet augmentation activity of prepared extract.

The main objective of the present study is to evaluate the platelet augmentation activity of $A$. paniculata extract (APE) and its active constituent Andrographolide (ANDLE) by using CPx induced thrombocytopenia model in Sprague Dawley rats. Effect of prepared extract on bleeding and clotting time also studied simultaneously because thrombocytopenia is associated with bleeding time and 
clotting time. Both the protective and preventive effects of $A$. paniculata extract and Andrographolide were evaluated in the study.

\section{Material and methods}

paniculata aerial parts were obtained from Tamilanadu, India; Cyclophosphamide and Andrographolide were purchased from Sigma-Aldrich Co, St Louis, MO, USA.

\section{Animals}

Male Sprague Dawley rats were purchased from National Institute of Nutrition (NIN), Hyderabad and permission was taken from institutional animal ethics committee of National Institute of Pharmaceutical Education And Research, Hyderabad and acclimatized for 7 days in animal house of the institute at $20-22^{\circ} \mathrm{C}, 12$ hours under light and 12 hours under dark in animal cages. Feed and water was provided to all animals during study period. After 7 days animals were grouped into five groups each group consists of 6 animals.

\section{Experimental protocol}

Preparation of aqueous extract: Aqueous extract of $A$. paniculata is prepared by extracting 100 grams of dried aerial parts of plant with $1000 \mathrm{ml}$ of hot water on magnetic stirrer with hot plate for 1 hour. The decoction is filtered and the clear filtrate is collected. The remained residue is re extracted twice with hot water and filtered. The obtained filtrates were combined and concentrated in a rotary vacuum evaporator under reduced pressure at $45^{\circ} \mathrm{C}$. Then the concentrated filtrate is freeze dried to obtain crude, dried extract of $A$. paniculata. ${ }^{11,12}$

Induction of thrombocytopenia: Before inducing thrombocytopenia, platelet count, bleeding time and clotting time were determined on day 1. Thrombocytopenia in Group B, C, D and E rats was induced by subcutaneous (S.C.) administration of CPx at a dose of $25 \mathrm{mg} / \mathrm{kg}$ for 3 days. ${ }^{13,14}$ On $7^{\text {th }}$ day all animals were investigated for development of thrombocytopenia.

Treatment of $\boldsymbol{A}$. paniculata Extract: Stock solution of APE was prepared by dissolving in normal saline and based on body weight the dose was administered orally to all four groups using oral gauge needle. Based on the results of the pilot study the doses were selected.

Treatment of Andrographolide: Andrographolide stock solution was prepared by dissolving the drug in small amount of DMSO and volume was made with distilled water. Then dose, volume of Andrographolide was calculated as per body weight and administered to Group 3,4 animals for 14days using oral gauge needle. For Group 5 and 6 animals Andrographolide was given from day 1 onwards along with Cpx. Blood samples were collected after 14days of treatment with Andrographolide for platelet count determination.

Determination of platelet count: Blood samples were collected on day 7 and 21 of treatment through retro orbital region in K3 EDTA tubes for platelet count determination. ${ }^{15}$ Platelet count was determined by using automated blood cell counter and conformed by microscopic evaluation. The platelet count was determined before treatment, seven days after CPx treatment and 14 days after treatment with extract.

Determination of bleeding time: Bleeding time was determined by modified duke's method. Animal was kept in a restrainers and the tail is exposed out. Animal tail was cleaned using hot water, rectified spirit and its tip was punctured using a sterile needle and blotted on what man filter paper until the bleeding was stopped. Bleeding time was recorded in terms of seconds. ${ }^{16,17}$
Determination of clotting time: Clotting time was determined by using capillary tube method. Capillary tube was filled with blood by puncturing retro orbital region and tube was broken for every 30 seconds until a fibrin thread appears. Clotting time was noted in terms of minutes. ${ }^{18}$

Determination of RBC count: $\mathrm{RBC}$ count was determined by using automated blood cell counter and conformed by microscopic evaluation.

\section{Statistical analysis}

Results were represented as figures. Mean +/- Standard Error of Mean (SEM) were calculated and compared using ANOVA. TwoWay ANOVA with Bonferroni's post-tests were performed to compare the groups. Significance at $\mathrm{P}<0.05$ was used for all comparisons. Statistical treatment of data was conducted using graph pad prism version-5 software.

\section{Results}

\section{Effect of A. paniculata extract on platelet count}

After treatment with CPx, platelet count was decreased significantly $(p<0.05)$. The fall in platelet count is due to the action of CPx, an alkylating agent caused the destruction of platelets by cytotoxic action. By suppressing bone marrow it may inhibit the production of megakaryocytes, the precursor cells of platelets. ${ }^{19}$

After 7days of CPx treatment, the platelet count was decreased from $8.071 \mathrm{akhs} / \mathrm{cmm}$ to $5.1 \mathrm{lakhs} / \mathrm{cmm}$ compared to baseline count in all the groups except Group A. APE administration significantly increased ( $5.73 \pm 0.20$ to $7.59 \pm 0.28 ; 6.02 \pm 0.27$ to $8.50 \pm 0.18$ ) (Figure 1) platelet production after 14 days of treatment. This increase in platelet count may be due to stimulation of thrombopoietin which plays key role in thrombopoiesis.

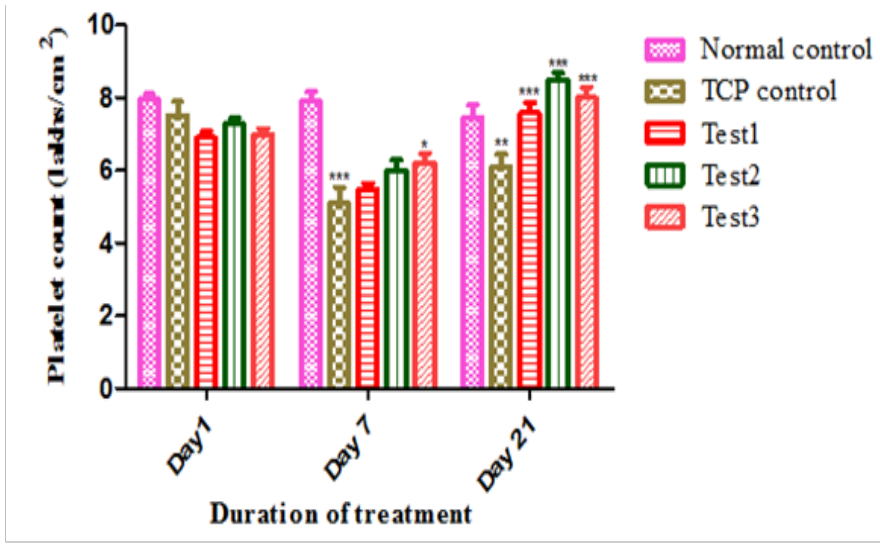

Figure I Effect of A. paniculata extract on platelet count.Values are expressed as Mean $\pm \operatorname{SEM}$ ( $n=6$ per group). There was a significant decrease in platelet count in TCP control group when compared to normal control group at $p<0.001$ on day 7 and $p<0.01$ on day 21 . After treatment with $A$. paniculata extract, platelet count was improved when compared to TCP control group at $\mathrm{p}<0.00$ I for Test I, Test 2 , on day 2 land for Test 3 at $\mathrm{p}<0.05$ on day $7, \mathrm{p}<0.00$ I on 21 respectively.

\section{Effect of A. paniculata extract on bleeding time}

Upon induction of thrombocytopenia with $\mathrm{CPx}$, bleeding time was increased compared to initial values. The increased bleeding time results in haemorrhage and leads to excess blood loss. ${ }^{20}$ When 
treated with APE bleeding time was decreased compared to CP treated group. In Group $\mathrm{C}$ and D bleeding time was decreased from $50.5 \pm 2.38$ to $27.16 \pm 1.49,53.16 \pm 2.36$ to $26.66 \pm 2.08$ respectively in a dose dependant manner compared to Group B (53.66 \pm 2.82$)$. The decrease in bleeding time is less in Group E, from $37.33 \pm 1.59$ to $28.33 \pm 1.05$, when compared to $\mathrm{C}$ and $\mathrm{D}$, indicates protective effect of $\mathrm{APE}$ is more significant $(\mathrm{P}<0.05)$ than preventive effect (Figure 2) (Table 1).

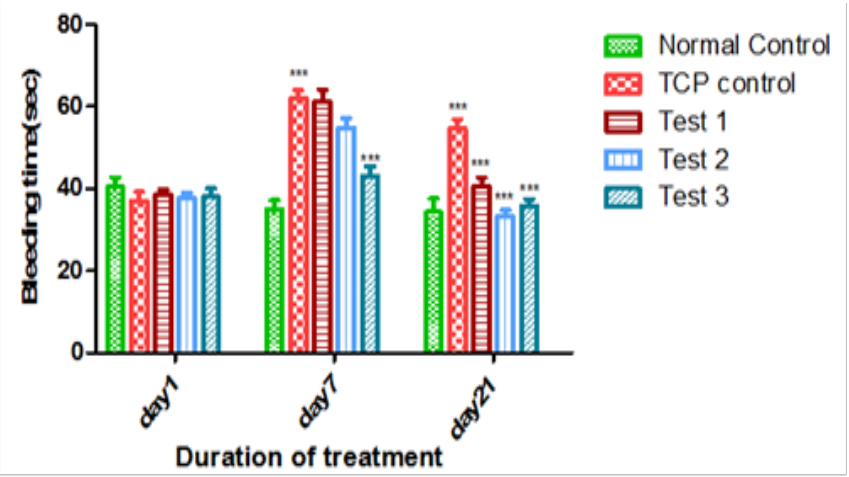

Figure 2 Effect of $A$. paniculata extract on bleeding time.Values are expressed as Mean \pm SEM ( $n=6$ per group).There was a significant increase in bleeding time in TCP control group when compared to normal control group at $p<0.001$ on day 7 and day 21 . After treatment with A. paniculata extract, bleeding time was reduced when compared to TCP control group at $\mathrm{p}<0.00 \mathrm{I}$ for Test I, Test 2 on day 21 and for Test 3 at $p<0.001$ on day 7 , day 21 respectively.

Table I Study design for platelet augmentation of AEAP

\begin{tabular}{|c|c|c|c|}
\hline Group & $\begin{array}{l}\text { No. of } \\
\text { Animals }\end{array}$ & Treatment & Treatment Duration \\
\hline Group-A & 6 & Normal Control & Vehicle (saline) \\
\hline Group-B & 6 & $\begin{array}{l}\text { Cyclophosphamide } \\
\text { (Cpx) } 25 \mathrm{mg} / \mathrm{kg} \\
\text { (Thrombocytopenia } \\
\text { control) }\end{array}$ & $\begin{array}{l}\text { CP. Once in a day for } \\
\text { consecutive three days }\end{array}$ \\
\hline Group-C & 6 & $\begin{array}{l}\text { CP + AEAP } 200 \mathrm{mg} / \mathrm{kg} \\
(\text { Test l) }\end{array}$ & $\begin{array}{l}\text { CP. Once in a day for } \\
\text { consecutive three days } \\
\text { and after } 7 \text { days AEAP } \\
\text { treatment for } 14 \text { days }\end{array}$ \\
\hline Group-D & 6 & $\begin{array}{l}\text { CP+ AEAP } 400 \mathrm{mg} / \mathrm{kg} \\
\text { (Test2) }\end{array}$ & $\begin{array}{l}\text { CP. Once in a day for } \\
\text { consecutive three days } \\
\text { and after } 7 \text { days AEAP } \\
\text { treatment for } 14 \text { days }\end{array}$ \\
\hline Group-E & 6 & $\begin{array}{l}\text { CP + AEAP } 400 \mathrm{mg} / \mathrm{kg} \\
(\text { Test } 3)\end{array}$ & $\begin{array}{l}\text { CP. Once in a day } \\
\text { and AEAP from day I } \\
\text { onwards }\end{array}$ \\
\hline
\end{tabular}

\section{Effect of A. paniculata extract on clotting time}

After inducing thrombocytopenia with $\mathrm{CP}$, in animals (Group B, C, D) clotting time was increased compared to Group A. Upon treatment with APE clotting time was decreased when compared to CPx treated group. When compared with Group B $(4.33 \pm 0.35)$, in Group $\mathrm{C}$ and $\mathrm{D}$, the clotting time was decreased from $4.30 \pm 0.30$, to $2.50 \pm 0.34,3.63 \pm 0.20$, to $2.01 \pm 0.32$ respectively. The decrease in clotting time was dose dependant. As like above, the clotting time is more in Group E ( $3.4 \pm 0.56$ to $2.26 \pm 0.34)$ when compared to $\mathrm{C}$ and $\mathrm{D}$, indicates protective effect of APE is significant $(\mathrm{P}<0.05)$ (Figure 3 ).

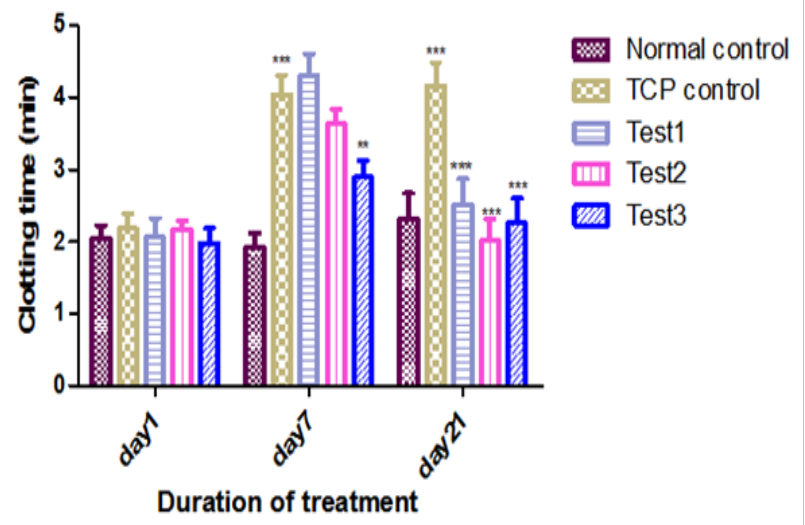

Figure 3 Effect of $A$. paniculata extract on clotting time.Values are expressed as Mean \pm SEM ( $n=6$ per group). There was a significant increase in clotting time in TCP control group when compared to normal control group at $p<0.00$ I on day 7 and day 21 . After treatment with A. paniculata extract, clotting time was decreased when compared to TCP control group at $p<0.001$ for Test I and Test 2 on day 21 and for Test $3 p<0.05$ on day 7 and $p<0.001$ on day 21 respectively.

\section{Effect of A. paniculata on RBC count}

$\mathrm{RBC}$ count was done in all the groups. As presented in Table 2, $\mathrm{CPx}$ treated groups has shown significant reduction in $\mathrm{RBC}$ count (Anaemia) (from $7.68 \pm 0.14$ to $5.13 \pm 0.11$ ) compared to normal control group. After treatment with APE there was no much significant change in the RBC count which indicates that APE has no effect on $\mathrm{CP}$ induced anaemia.

Table 2 Study design for platelet augmentation of Andrographolide

\begin{tabular}{llll}
\hline Group & $\begin{array}{l}\text { No. of } \\
\text { Animals }\end{array}$ & Treatment & $\begin{array}{l}\text { Treatment } \\
\text { Duration }\end{array}$ \\
\hline Group-I & 6 & Normal control & Vehicle (saline) \\
Group-2 & 6 & $\begin{array}{l}\text { Cyclophosphamide } \\
\text { (Cpx) } 25 \mathrm{mg} / \mathrm{kg} \\
\text { (Thrombocytopenia } \\
\text { control) }\end{array}$ & $\begin{array}{l}\text { Cpx. Once in a day for } \\
\text { three days }\end{array}$ \\
\hline
\end{tabular}

$\begin{array}{clll} & & \text { Cpx }+ & \text { Cpx Once in a day for } \\ \text { Group-3 } 6 & \begin{array}{l}\text { Andrographolide } \\ (3 \mathrm{mg} / \mathrm{kg})\end{array} & \begin{array}{l}\text { three days and after 7 } \\ \text { days ANDLE treatment } \\ \text { for 14 days }\end{array}\end{array}$

$\begin{array}{ccl}\text { Group-4 } 6 & \begin{array}{l}\text { Cpx+ } \\ \text { Andrographolide } \\ (6 \mathrm{mg} / \mathrm{kg})\end{array}\end{array}$

Cpx. Once in a day for three days and after 7 days ANDLE treatment for 14 days

$\begin{array}{clll}\text { Group-5 } 6 & \begin{array}{l}\text { Cpx +ANDLE } \\ (3 \mathrm{mg} / \mathrm{kg})\end{array} & \begin{array}{l}\text { Cpx. Once in a day and } \\ \text { ANDLE from day I } \\ \text { onwards }\end{array}\end{array}$

$\begin{array}{lll}\text { Group-6 } 6 & \begin{array}{l}\text { Cpx }+ \text { ANDLE } \\ (6 \mathrm{mg} / \mathrm{kg})\end{array}\end{array}$

Cpx. Once in a day and ANDLE from day I onwards 


\section{Effect of Andrographolide on platelet count}

After induction of thrombocytopenia with $\mathrm{Cpx}$, there was a significant fall in platelet count $(6.48 \pm 0.25$ to $4.46 \pm 0.27 \mathrm{lakhs} / \mathrm{cmm})$ was observed in TCP alone group compared to normal control. Andrographolide treatment for 14 days countered $4.97 \pm 0.27$ to $7.24 \pm 0.34 ; 5.03 \pm 0.12$ to $7.58 \pm 0.45$ ) the fall in platelet count. In case of Test 3 and Test 4 groups, treatment of Andrographolide for 21 days prevented the development of thrombocytopenia, CP induced toxicity and also a significant improvement in platelet count was also observed (Figure 4) (Table 3).

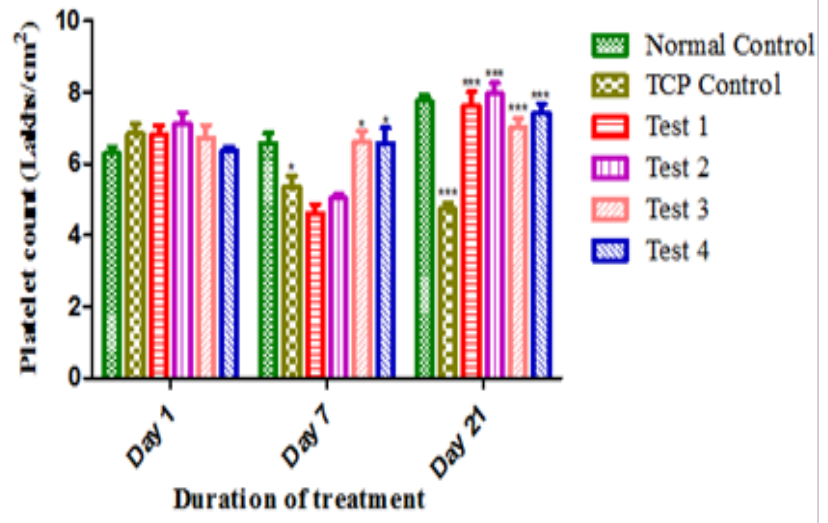

Figure 4 Effect of Andrographolide on platelet count.Values are expressed as Mean \pm SEM ( $n=6$ per group). There was a significant decrease in platelet count in TCP control group when compared to normal control group at $p<0.05$ on day 7 and $p<0.001$ on day 21 . After treatment with Andrographolide, platelet count was improved when compared to TCP control group at $p<0.00 \mathrm{I}$ for Test I, Test 2, on day $2 \mathrm{I}$ and for Test 3 , Test 4 at $p<0.05$ on day 7 and $p<0.00$ I on $2 \mathrm{I}$ respectively.

Table 3 Effect of A. paniculata extract on RBC count

\begin{tabular}{llll}
\hline \multirow{2}{*}{ Group } & \multicolumn{2}{l}{ RBC (Lakhs/Cumm) (Mean \pm SEM) } \\
\cline { 2 - 4 } & Day I & Day7 & Day 2 I \\
\hline Normal Control & $7.38 \pm 0.10$ & $7.43 \pm 0.13$ & $7.4 \pm 0.15$ \\
TCP Control & $7.68 \pm 0.14$ & $5.13 \pm 0.11$ & $4.93 \pm 0.08$ \\
Test I & $7.21 \pm 0.07$ & $5.91 \pm 0.19$ & $5.23 \pm 0.06$ \\
Test 2 & $7.41 \pm 0.10$ & $5.2 \pm 0.04$ & $5.20 \pm 0.18$ \\
Test 3 & $7.60 \pm 0.15$ & $5.35 \pm 0.17$ & $5.13 \pm 0.13$ \\
\hline
\end{tabular}

\section{Effect of Andrographolide on bleeding time}

When treated with Cpx, bleeding time was increased significantly $(28 \pm 0.81$ to $72.8 \pm 3.75)(\mathrm{p}<0.05)$ compared to normal control group on day 7. After treatment with Andrographolide, bleeding time was reduced $(67.16 \pm 2.08$ to $35.83 \pm 1.47 ; 67.16 \pm 1.74$ to $30.16 \pm 1.98)$ compared to TCP control group significantly. At the end of study, it is observed that there is no much difference between low dose $(3 \mathrm{mg} / \mathrm{kg})$ and high dose $(6 \mathrm{mg} / \mathrm{kg})$ of Andrographolide on bleeding time (Figure $5)$.

\section{Effect of Andrographolide on clotting time}

After treatment of $\mathrm{Cpx}$, clotting time was increased significantly
$(2.14 \pm 0.08$ to $3.61 \pm 0.21)(\mathrm{p}<0.05)$ due to the lack of sufficient number of platelet in the peripheral blood. When treated with Andrographolide, clotting time was significantly decreased $(3.30 \pm 0.25$ to $2.27 \pm 0.06$; $3.54 \pm 0.16$ to $1.93 \pm 0.15)$ and became to almost normal level as like on day 1. After 21 days it was also observed that there is no much increase in clotting time in the case of Test 3 and Test 4 due to the treatment of Andrographolide from day 1 onwards along with $\mathrm{Cpx}$ (Figure 6).

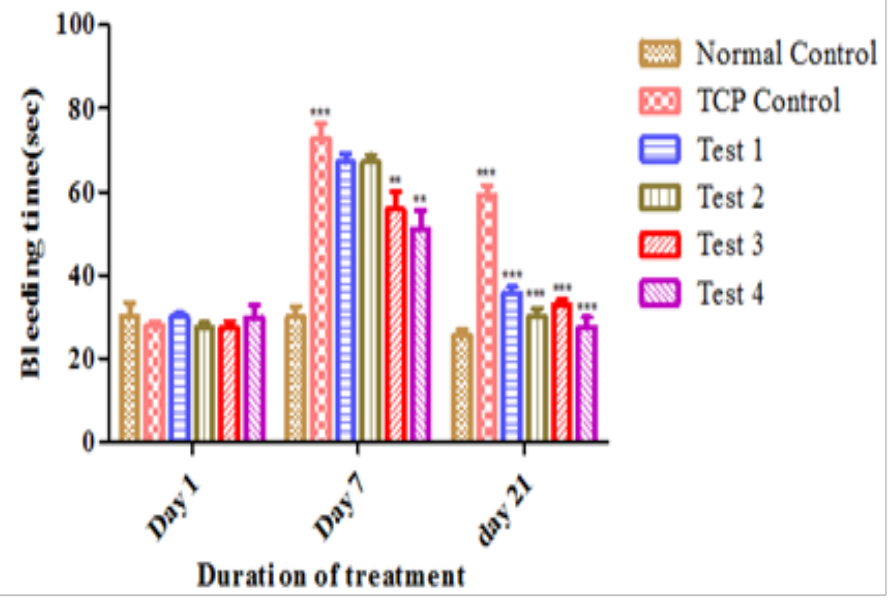

Figure 5 Effect of Andrographolide on bleeding time.Values are expressed as Mean \pm SEM ( $n=6$ per group). There was a significant increase in bleeding time in TCP control group when compared to normal control group at $p<0.00$ I on day 7 and day 21 . After treatment with Andrographolide, bleeding time was reduced when compared to TCP control group at $\mathrm{p}<0.00$ I for Test I, Test 2 on day 21 and for Test 3 , Test 4 at $p<0.01$ on day 7 and $p<0.001$ on day 21 respectively.

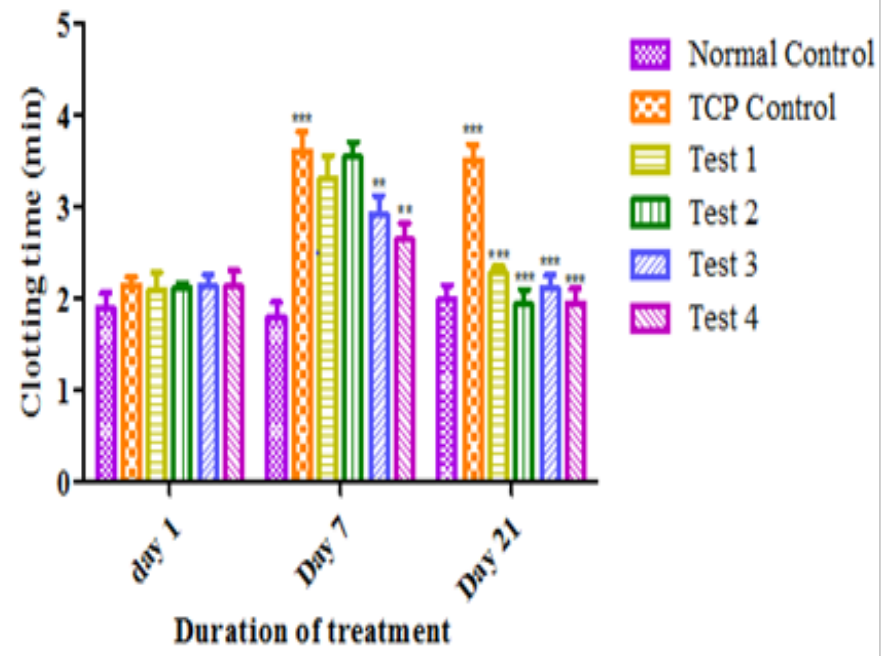

Figure 6 Effect of Andrographolide on clotting time. Values are expressed as Mean \pm SEM ( $n=6$ per group). There was a significant increase in clotting time in TCP control group when compared to normal control group at $p<0.001$ on day 7 and day 21 . After treatment with Andrographolide, clotting time was decreased when compared to TCP control group at $p<0.00 \mathrm{I}$ for Test I and Test 2 on day $2 \mathrm{I}$ and for Test 3 and Test 4 at $p<0.01$ on day 7 and $p<0.00$ I on day $2 \mathrm{I}$ respectively.

\section{Discussion}

The present study was conducted to evaluate the platelet 
augmentation activity of $A$. paniculata aqueous extract and its active constituent Andrographolide by using $\mathrm{CPx}$, an alkylating agent as per previous studies. CPx at $25 \mathrm{mg} / \mathrm{kg}$ was induced stable thrombocytopenia in rats without causing mortality. It can induce the thrombocytopenia by suppressing the production of megakaryocytes from bone marrow, which is the site of blood cell production.

In India, the most common cause of thrombocytopenia is dengue fever, in which thrombocytopenia is a result of platelet sequestration, destruction, and bone marrow suppression. ${ }^{21,22}$ Thrombocytopenic disorder having limited supportive treatments, hence studies on herbal medicinal products for its treatment are increasing significantly. In the present study, after treatment with $A$. paniculata extract and Andrographolide in thrombocytopenic rats a significant $(\mathrm{p} \leq 0.001)$ increase in platelet count was observed. These finding are correlating with the results of other studies and justifies its traditional use in the treatment of dengue fever in Indian sub continent. The mechanism behind $\mathrm{CPx}$ induced thrombocytopenia and dengue virus induced thrombocytopenia are similar i.e. bone marrow suppression..$^{23}$ Hence A. paniculata extract and Andrographolide may also effective to treat dengue virus induced thrombocytopenia.

The findings revealed that $A$. paniculata contains active constituents (Andrographolide) with haemostatic property and significant decrease $(p \leq 0.001)$ in bleeding time and clotting time were observed which may be due to increased production of platelets. These results are correlating with reported literature. ${ }^{24}$

Under normal healthy body conditions, platelets are produced from megakaryocytes within 4 to 6 days. ${ }^{25}$ In this study an increase of platelets was observed within two weeks. Under normal healthy body conditions spleen tends to hold one third of the platelets produced by megakaryocytes. ${ }^{26}$ The smooth muscle contraction of the spleen, release stored platelets in to the circulation. Hence it is hypothesising that the platelet augmentation effect of the A. paniculata extracts and Andrographolide is either due to megakarypoietic stimulatory activity and or to induce splenic contractions. The effect of these two mechanisms may also responsible. Treatment A. paniculata and Andrographolide may also cause the recovery of platelet production by enhancing the release of thrombopoietin from liver which plays a role in thrombopoiesis.

The results obtained reveal that, A. paniculata and its chemical constituent Andrographolide treatment may have beneficial effect in dengue hemorrhagic fever. In this study we observed that, $A$. paniculata extract alone exhibited protective effect in dose dependant manner and preventive effect at high dose $(400 \mathrm{mg} / \mathrm{kg})$. The high dose of $A$. paniculata extract does not affect the RBC count. Andrographolide alone also showed platelet augmentation activity. At the end of study with Andrographolide, it was observed that, there is no much difference between low $(3 \mathrm{mg} / \mathrm{kg})$ and high dose $(6 \mathrm{mg} /$ $\mathrm{kg}$ ) of Andrographolide on platelet count. It is acknowledged that the platelet increasing activity of the $A$. paniculata is mainly due to its active constituent Andrographolide.

\section{Conclusion}

The whole study is observed in view of the recent epidemics in some states of India, where in the dengue virus infection induces, dengue shock syndrome, which is an acute condition and lethal. This study scientifically claimed for the first time that the $A$. paniculata and Andrographolide is safe and effectively increased platelet count in thrombocytopenic rats and justifies the claim of its traditional use. Hence Andrographolide is a potential candidate for further research leading to the development of an herbal therapeutic agent for thrombocytopenia due to dengue fever.

\section{Acknowledgements}

Authors are thankful to Ministry of Chemicals and Fertilizers, Govt. of India for providing financial support.

\section{Conflict of interest}

The author declares no conflict of interest.

\section{References}

1. Saranya P, Geetha A, Narmadha Selvamathy S. The antioxidant and $\mathrm{H}^{+}$ $\mathrm{K}+$ ATPase inhibitory effect of Andrographis paniculata and andrographolide-in vitro and in vivo studies. Pharmacologyonline. 2010;1:356376.

2. Chandrasekaran CV, Thiyagarajan P, Sundarajan K, et al. Evaluation of the genotoxic potential and acute oral toxicity of standardized extract of Andrographis paniculata (KalmCold $\left.{ }^{\mathrm{TM}}\right)$. Food and Chemical Toxicology. 2009;47(8):1892-1902.

3. Akbar S. Andrographis paniculata:a review of pharmacological activities and clinical effects. Alternative Medicine Review. 2011;16(1):66-77.

4. Ojha SK, Bharti S, Joshi S, et al. Protective effect of hydroalcoholic extract of Andrographis paniculata on ischaemia-reperfusion induced myocardial injury in rats. Indian J Med Res. 2012;135:414-421.

5. Jarukamjorn K, Nemoto N. Pharmacological aspects of Andrographis paniculata on health and its major diterpenoid constituent andrographolide. Journal of Health Science. 2008;54(4):370-381.

6. Eissa LA, Gad LS, Rabie AM, et al. Thrombopoietin level in patients with chronic liver diseases. Ann Hepatol. 2008;7(3):235-244.

7. Zeuner A, Signore M, Martinetti D, et al. Chemotherapy-induced thrombocytopenia derives from the selective death of megakaryocyte progenitors and can be rescued by stem cell factor. Cancer Res. 2007;67(10):4767-4773.

8. Visentin GP, Liu CY. Drug-Induced Thrombocytopenia. Hematol Oncol Clin North Am. 2007;21(4):685-696.

9. Kim EJ, Lim KM, Kim KY, et al. Doxorubicin-induced platelet cytotoxicity:a new contributory factor for doxorubicin-mediated thrombocytopenia. J Thromb Haemost. 2009;7(7):1172-1183.

10. Greenberg EM, Kaled ES. Thrombocytopenia. Critical Care Nursing Clinics of North America. 2013;25(4):427-434.

11. Thisoda P, Rangkadilok N, Pholphana N, et al. Inhibitory effect of $A n-$ drographis paniculata extract and its active diterpenoids on platelet aggregation. Eur J Pharmacol. 2006;553(1-3):39-45.

12. Zhang C, Tan B. Mechanisms of cardiovascular activity of Andrographis paniculata in the anaesthetized rat. $J$ Ethnopharmacol. 1997;56(2):97101.

13. Swati Patil, Supritha Shetty, Rama Bhide, et al. Evaluation of Platelet Augmentation activity of Carica papaya Leaf Aqueous Extract in Rats. Journal of Pharmacognosy and Phytochemistry. 2013;1(5):57-60.

14. Kristiana H, Nailufar F, Winoto IL, et al. A model of rat thrombocytopenia induced by cyclophosphamide. Dipersembahkan Untuk Kemajuan Ilmu Pengetahuan dan Teknologi Kefarmasian di Indonesia. 2013;6(3):177 
15. Butkiewicz AM, Kemona H, Dymicka-Piekarska V, et al. Platelet count mean platelet volume and thrombocytopoietic indices in healthy women and men. Thromb Res. 2006;118(2):199-204.

16. Elg M, Carlsson S, Gustafsson D. Effects of agents, used to treat bleeding disorders, on bleeding time prolonged by a very high dose of a direct thrombin inhibitor in anesthesized rats and rabbits. Thromb Res. 2001;101(3):159-170.

17. Stupnisek M, Franjic S, Drmic D, et al. Pentadecapeptide BPC 157 reduces bleeding time and thrombocytopenia after amputation in rats treated with heparin, warfarin or aspirin. Thromb Res. 2012;129(5):652-659.

18. Garcia-Manzano A, Gonzalez-Llaven J, Lemini C, et al. Standardization of rat blood clotting tests with reagents used for humans. Proc West Pharmacol Soc. 2001;44:153-156.

19. Sekhon SS, Roy V. Thrombocytopenia in adults: a practical approach to evaluation and management. South Med J. 2006;99(5):491-498.

20. Apostol JG, Gan JVA, Raynes RJB. Platelet-Increasing Effects of Euphorbia hirta Linn. (Euphorbiaceae) in Ethanol-Induced Thrombocytopenic Rat Models. IJPFR. 2012;2:1-11.
21. Lei HY, Yeh TM, Liu HS, et al. Immunopathogenesis of dengue virus infection. J Biomed Sci. 2001;8(5):377-388.

22. Akomas S, Ijioma S. Bleeding and clotting time effect of ethanolic extracts of chromolaena odorata versus ocimum gratissimum treated albino rats. Comprehensive Journal of Medical Sciences. 2014;2(1):9-13.

23. Li J, Yang C, Xia Y, Bertino A, et al. Thrombocytopenia caused by the development of antibodies to Thrombopoietin. Blood. 2001;98(12):32413248 .

24. Sheu JR, Lee CR, Lin CH, et al. Mechanisms involved in the antiplatelet activity of Staphylococcus aureus lipoteichoic acid in human platelets. Thromb Haemost. 2000;83(5):777-784.

25. Choi ES, Nichol JL, Hokom MM, et al. Platelets generated in vitro from proplatelet-displaying human megakaryocytes are functional. Blood. 1995;85(2):402-413.

26. Alva J, Thapar M. Increasing low platelets instantly. WIPO Patent Application; International Publication No:WO-2010/041263; A1.0; 2010. 